\title{
LATVIS „DABARTINĖS LIETUVIŲ KALBOS TEKSTYNO“ PASAULĖVAIZDYJE
}

\author{
Loreta VAIČIULYTĖ-SEMĖNIENĖ \\ Lietuvių kalbos institutas
}

\section{1. İvadas}

Apie artimiausią lietuvio kaimyną latvị ${ }^{1}$ rašyta nemažai įvairiais aspektais - istoriniu, kultūros antropologiniu, sociologiniu, socialiniu psichologiniu, etnologiniu, kalbiniu. Nepretenduojant apžvelgti visko², minètini darbai, kur kalbama apie latviui būdingus būdo bruožus lietuvio akimis. Pavyzdžiui, Dalia Senvaitytė (2004: 125), remdamasi lietuvių tautybès studentų apklausų rezultatais, teigia, kad latvis yra draugiškas, nuoširdus, mandagus, linksmas, santūrus ${ }^{3}$. Tai, kad latvis yra toks kaip lietuvis, nurode 11 procentų respondentų (t. p.: 127). O pats lietuvis, respondentų nuomone, yra darbštus, taupus, pavydus, abejingas, savanaudis, uždaras ${ }^{4}$. Autorè (Senvaitytė 2004: 128) atkreipia dèmesị ị tai, kad latviai yra viena iš mažiausiai lietuviui pažistamų tautų, ir mano, kad taip atsitiko ,[g]albūt todèl, kad žiniasklaida, kino filmai, literatūra mažai „populiarina“ ju įvaizdị“. Tai, kad „kas yra arčiausia, nebūtinai yra geriausiai pažįstama“, tvirtina ir Silvija PapaurèlytėKlovienė. Ji (Papaurèlytė-Klovienė 2010: 7), remdamasi būdvardžių latviškas, - $a$ formų junginiais su charakterio bruožus pavadinančiais žodžiais iš Kauno Vytauto Didžiojo universiteto Kompiuterinès lingvistikos centre kaupiamo Dabartinés lietuviu kalbos tekstyno, daro išvadą, kad „[s]u Lietuva tiesiogiai besiribojančių Latvijos [...] atstovų nacionalinis charakteris lietuvių kalbos

1 Šiame straipsnyje kalbant apie latvius apibendrintai vartojama vienaskaitos latvis forma. Plg. „V litovskom jazyke obyčno imenno edinstvennoe čislo imeet obobščennoe značenie i ispol'zuetsja v otnošenii kak gruppy ljudej, tak i otdel'nogo individa“ (Kvašyte 2012: 88).

2 Tyrinėjimų apžvalgą įvairiais aspektais plačiau žr. Noreikaitė (2013: 6tt; 2017: 17t ir ten cituojamą literatūrą); Boldāne (2014: 140tt ir ten cituojamą literatūrą).

3 Plg. „Latviai - vienintelè tautybė, su kuria respondentai buvo linkę gretinti save, t. y. lietuvius. Net 11 procentų respondentų nurodé, kad latviai būdo bruožais (tiek teigiamais, tiek neigiamais) nesiskiria nuo lietuvių. Tačiau nurodydami konkrečias savybes, studentai latvius apibūdino daug teigiamiau - manè juos esant draugiškus, nuoširdžius, mandagius“ (Senvaitytė 2004: 125).

4 Plg. „Pagrindinès nurodytos teigiamos lietuvių savybès - darbštumas ir taupumas. Tačiau lietuviams esą būdingas ir pavydumas, savanaudiškumas, abejingumas visiems kitiems, viskam, kas su jais asmeniškai nesusiję“ (Senvaitytė 2004: 125). „Lietuvio autostereotipo branduoli sudaro darbštumas ir pavydumas“ (t. p.: 127). Dar apie lietuvio autostereotipą žr. Ryžakova, Zavíjalova (2008). 
pasaulèvaizdyje atspindėtas labai fragmentiškai“. Matyti, kad „Dabartinės lietuvių kalbos tekstyne [...] labai mažai pavyzdžių, kurie nusakytų artimiausių lietuvių kaimynų - latvių - charakterio specifiką. Peržiūrèta tik vos daugiau nei 100 sakinių, informacijos apie etninius stereotipus suteikia vos 4“. Papaurèlytė-Klovienè teigia, kai tai gali būti susiję su tuo, kad „greičiausiai apskritai mažai rašoma apie Latviją, jos gyventojus. Be to, tikètina, kad lietuvių kalbinėje sąmoneje latviai nesiejami su jokiais išskirtiniais bruožais. [...] Negausiuose pavyzdžiuose, kuriuose labai fragmentiškai užfiksuoti latvių nacionalinio charakterio bruožai figūruoja iš esmès tik teigiamai vertinami ar bent jau neutralūs dalykai“" (t. p.: 3).

Svetlana Ryžakova ir Marija Zavjalova (Ryžakova, Zav'jalova 2008), apklaususios 200 Vilniaus lietuvių ir Rygos latvių vyresniųjų klasių moksleivių (16-18 metų) ir šios anketinès apklausos pagrindu atlikusios etnopsicholingvistinį tyrimą, taip pat prièjo išvados, kad latvis ir lietuvis turi bendrų charakterio bruožų, bet jie nėra tapatūs (Ryžakova, Zav'jalova 2008: 151tt). Iš apklausų (Ryžakova, Zav́jalova 2008: 51t, 60t) paaiškejjo, kad tiek latvio, tiek lietuvio autostereotipo vieni iš aktualiausių charakterio bruožų yra šie: susivaržęs, uždaras, nekalbus, ramus. Be to, tiek vienas, tiek kitas mato save pavydų, darbštų, draugišką, linksmą, užsispyrusị, ištvermingą, patriotišką (Ryžakova, Zavíjalova 2008: 70t; dar plg. 75).

Čia aiškejja keletas dalykų. Nepaisant matomo panašumo, lietuvis latvio gerai nepažįsta, negali išskirti jo iš kitų. Kita vertus, būtent tarpusavio panašumas gali turèti ịtakos tam, kad lietuviui sunku išskirti latvị, nes jame, tikètina, mato save, suvokia jị kaip savo (aš) dalį. Kitaip sakant, latvio neišskirtinumas ir panašumas ị lietuvị susijęs su savumu, arba $\operatorname{art}(i m) u m u^{5}$.

Laima Anglickiené mini, kad tautosakos tekstuose latvis minimas kaip apgavikas, žiniuonis ar burtininkas, galintis ne tik padèti, bet ir turintis piktųju galių (Anglickienè 2006: 22t, 34, 77, 82t, 229tt). Iš Vilmos Daugirdaitès (2007) pateiktų žemaičių pasakojimų apie artimiausią kaimyną latvị aiškẻja, kad jis galis būti negudrus, keistenybiu keistenybé, nepinigingas, tikintis Dievu liuteronas, burtininkas. Be to, kad žemaitis latvị pažịsta kaip burtininką, kitatikį, Jūratė Pajẻdienè (2021) šiaurès vakarų žemaičių šnektų žodynų, tarminiu pokalbiu ir pasakojimų pagrindu dar teigia, kad latvis yra doras, atkaklus kaimynas, su kuriuo žemaitis kuria šeimą. Kita vertus, latvis gali būti žemaičio demonizuojamas. Ši tą apie latvio būdą sužinoti galima ir iš Reginos Kvašytès (2012) darbo, kur per išsamiai aptartus lietuvių ir latvių

5 „Artimumas (angl. proximity) - geografinis artumas. Artumas (kaip „funkcinis atstumas“) leidžia veiksmingai prognozuoti simpatiją“ (Myers 2008: 447). 
kalbų, kaip etninės savimonės raiškų, panašumus ir skirtumus, supažindinama ir su Lietuvoje arba Latvijoje gyvenančiais latviais. Pavyzdžiui, nagrinėdama Latvijos lietuvių šnekamąią kalbą, autorè (Kvašytė 2012: 90t) pavyzdžiuose mini, kad latvis mėgsta alų, yra svetingas, sukalbus, lepnus (išdidus), dainingas ir Dievu tikintis. Auksė Noreikaitė (2013, 2017) savo darbuose aptaria Lietuvos ir Latvijos pasienio regionuose, kaip savitoje kultūrinejje zonoje, gyvenančių lietuvių ir latvių tarpusavio santykius. Remdamasi lauko tyrimo medžiaga, ji parodo lietuvio ir latvio tarpusavio santykių ypatybes Šventosios, Skuodo, Žeimelio ir Biržų apylinkèse ir atskleidžia, kaip lietuvis ir latvis vertina vienas kitą. Remdamasi Laimos Anglickienès (2006: 61t) hierarchizuoto svetimo ${ }^{6}$ samprata, Noreikaite (2013: 33) teigia, kad „lietuviai ir latviai pastebi kitoniškumą, tačiau vieniems tai kliudo artimiau bendrauti, o kitiems neturi didelès reikšmès. Lietuviai ir latviai mažai akcentuoja savo / svetimo skirtį, pasakojimuose pabrèžiamas abiejų tautų vienodumas ir vienybė, taigi abi tautos viena kitai yra savos"“ (t. p.: 2, 54). Noreikaitė (2013: 25tt; dar

6 „Pagal tai, ką lietuviai vadina svetimu, būtų galima išskirti tam tikrus svetimumo lygius. Hierarchiškai svetimasis tai: 1. Priklausantis mitiniam pasauliui (Dievas; velnias, laumès ir t. t.). 2. Kitatikis. 3. Kitatautis. 4. Kitos socialinès grupès žmogus. 5. Kitos etnografinès srities žmogus. 6. Kitos vietovès, kaimo narys. 7. Kitos giminès, šeimos žmogus“ (Anglickienė 2006: 61t).

7 „2010-2011 m. atlikus tyrimą su Vilniaus ir Kauno latviais paaiškejjo, kad latviams tapti „savais“ lietuvių miestiečių visuomenėje nèra sudètinga: toks pat antropologinis tipas, panašūs tradiciniai vardai, pramokta lietuvių kalba - to užtenka, kad „,taptum“ lietuviu. Tačiau kaime galioja kiek kitokios taisyklès. Čia vietiniai žmonės gerai žino visų savo vietovės gyventojų gyvenimo istorijas ir daugiau ar mažiau kiekvieno gyventojo geneologiją. Būtent šios žinios lietuviams neleidžia latvio iš ne mišrios šeimos, bet pakeitusio savo savimonę, laikyti lietuviu“ (Noreikaite 2013: 52). Apie tai, kad Žeimelyje lietuvių ir latvių bendruomenès ,per ilgą laiką susigyvenusios ị vieną“, dar žr. Jonutytė (2013: 173).

Numanomas lietuvio ir latvio panašumas, savumas, galbūt, turi įtakos ir tam, kad, atliekant lietuvio nuostatų tyrimus etninių grupių atžvilgiu, latvis neįtraukiamas ị apklausas. Pavyzdžiui, klausimo „Pasakykite su kuo iš išvardytų žmonių grupių Jūs nenorètumète gyventi kaimynysteje“ galimuose pasirinkti atsakymuose latvio nèra, bet minimi kiti $\operatorname{artim(esn)i~ir~tolim(esn)i~lietuvio~kaimynai:~totoriai,~romai~(čigonai),~kinai,~čečènai,~žydai,~}$ rusai, baltarusiai, lenkai, kazachai, turkai, gruzinai, ukrainiečiai, turkai, pakistaniečiai (Petrušauskaitė 2013: 187).

Tai, kad lietuvio ir latvio panašumas turi įtakos tyrimo objektui, spėtina ir skaitant Vytauto Židonio (2010) darbą, kur tekstynų lingvistikos metodu tiriamos etnonimų: čigonas, romas, žydas, karaimas, rusas, lenkas, reikšmès. Viena vertus, autorius teigia, kad „lietuviams aktualiausi etnonimai yra tie, kurie įvardija Lietuvoje gyvenančias etnines mažumas ir kaimyninių valstybių gyventojus, nes su jais turi glaudžiausius kontaktus“ (Židonis 2010: 5) ir viena iš priežasčių pasirinkti tirti minètų etnonimų reikšmes „yra populiacijos dydis“ (Židonis 2010: 14). Kita vertus, matyti (t. p.: 12), kad, nepaisant to, jog latvių mažuma Lietuvoje yra ir tokia pati $(0,1$ proc.) kaip darbe tiriamų žydų ir net kiek didesnè už tiriamus karaimus (0,0076 proc.), latviai netiriami. Tyrimo objekto pasirinkimą lemia numanomas 
žr. t. p.: 54; 2017: 25), išnagrinejjusi Lietuvos pasienyje gyvenančio lietuvio požiūrị ị šalia gyvenantị Lietuvos latvị, daro išvadą, kad išryškejjo skirtingas lietuvio požiūris: Šventosios ir Skuodo apylinkių lietuviai (žemaičiai) „daugiau papasakoti galëjo tik apie tuos latvius, pas kuriuos tekdavo gyventi ar dirbti bei apie visoje apylinkèje pagarsẻjusius latvių burtininkus“; „Žeimelio apylinkių lietuviai [...] teigè, kad lietuviai ir latviai yra labai panašūs, daugelị stebino tik latvių laidotuvių tradicijos. Biržų apylinkių lietuviai negalèjo įvardyti lietuvių ir latvių kultūros skirtumų, nes daugelis šio krašto lietuvių laikèsi latviškų papročių ir net šeimose kalbẻdavo latviškai. Tačiau čia lietuviai atkreipe dėmesị į charakterio skirtumus. Lietuviai pasižymėjo nuolaidumu, o latviai buvo arogantiški, žinojo savo vertę“.

Iš to, kas trumpai sakyta, aiškejja, kad tai, kaip / ar skirtingai vertinamas latvis visų pirma susiję su pačiu vertinančiuoju - lietuviu ${ }^{8}$ Kitaip sakant, kitas, latvis, matomas aš, lietuvio, akimis (plg. Ant [kontoros] sienos kabëjo mažytis Leninukas, tikras turkas (kai lietuviai piešdavo Lenina, visad jis išeidavo panašus ị lietuvị, latviams ị latvị...) DLKT). Veidrodžio principas leidžia matyti tiek kito, tiek savo vidines nuostatas ${ }^{9}$. Tarpusavio panašumas susijęs su latvio artumu, skirtumas - su savitumu. Reziumuotų darbų pagrindu dèliojasi dvejopas - lietuvio (ne)palankiai vertinamas - latvio paveikslas: jis yra doras, tikintis, pasitikintis, darbštus, draugiškas, nuoširdus, mandagus, svetingas, linksmas, ramus, ištvermingas, patriotiškas ir atvirkščiai - susivaržęs, uždaras, išdidus, pavydus, arogantiškas, užsispyręs, keistas, kaip velnias, negudrus ir pan. Apžvelgtuose darbuose matomą latvio paveikslą vertinant semantiniais žmogaus aspektais (Sakalauskienè 2018: 182tt), apie latvį pasakoma psichiniu, psichologiniu (doras, ramus, linksmas ir pan.) (psicho)socialiniu (draugiškas, svetingas, mandagus ir pan.), fiziniu (ištvermingas ir pan.), buitiniu (neturtingas, alaus mėgejas ir pan.) ir lokaliniu (gyvenantis ir Lietuvoje) aspektu. Toliau semantiniai aspektai bus latvio aptarimo pagrindu.

požiūrio ị tiriamas tautas skirtumas: „Čigonų (kitaip romų) ir karaimų Lietuvoje palyginus nẻra daug, tačiau jau iš anksto galima pastebèti vertinimo skirtumus: čigonai yra vertinami neigiamai, o karaimai [...] yra bene vienintelè tauta, kurios vartosenos kontekstai žymiai skirsis nuo kitų. Todèl šie pasirinkti tam, kad būtų kontrastas kitiems etnonimams ir pabrěžtų skirtingą etnonimų vartoseną“ (Židonis 2010: 14).

8 Plg. „Kitas yra lemiamas dèmuo, suvokiant save kaip žmogų, nes kito „atradimas“ yra ir savęs ,atradimas“““ (Cidzikaitė 2007: 66).

„Ved' ètničeskij stereotip, daže opisyvajuščij «drugogo», èto počti vsegda nemnožko rasskaz i o sebe“ (Ryžakova, Zav'jalova 2008: 18t).

9 „Nuostata - palanki arba nepalanki kokio nors dalyko arba asmens vertinimo reakcija, dažnai grindžiama įsitikinimais, o išreiškiama jausmais ir elgesio ketinimais“ (Myers 2008: 153). 
Šio straipsnio tikslas - aprašyti latvio koncepto ${ }^{10}$ fragmentą kaip pasaulèvaizdžio žmogaus sąmonèje dalị, tam tikrą suvokimo būdą, kuris išryškejja iš DLKT publicistikos pavyzdžių, kur minimas daiktavardis latvis, latve skirtingomis formomis ${ }^{11}$. Keliamas klausimas, kaip vartosenoje per formalią struktūrą aktualizuojama mentalinè struktūra. Tikslui pasiekti išsikelti uždaviniai - minèti, kaip latvis yra apibrèžiamas aiškinamuosiuose lietuvių kalbos žodynuose; išanalizuoti skirtingas kalbamojo žodžio formas minimaliuose dabartinès lietuvių kalbos fragmentuose - sakinyje ir analizės pagrindu nustatyti, kaip per raišką skleidžiasi latvio turinio tendencijos ${ }^{12}$ - dabartinès lietuvių kalbos vartotojų sąmoneje egzistuojantis latvio paveikslas. Analizės nuošalyje paliekamas DLKT matomas latvio požiūris ị save ${ }^{13}$ arba lietuvị ${ }^{14}$, latvio kontekste matomas lietuvis (plg.: Gaila, kad [esu] tiktai sésli latvé su latviams būdingu mazochistiniu polinkiu nesugebèti pakišti nelaimès po akmeniu; Žaidime pasirodè esąs egoistas, neradęs geru žodžiu ne vienam kraštiečiui, bet jis juk - lietuvis, - taip studijoje susirinkusius lietuvius gèdino latviai; Lietuviai didesnę simpatija jaučia savo kaimynams - latviams ir estams, didesnę negu vokiečiams, baltarusiams, ukrainiečiams, lenkams (DLKT)). Tikètina, kad tai, kas jau sakyta apie latvi, pasitvirtins. Tyrimo metodai: semantinès analizès, aprašomasis, interpretacinis.

Straipsnyje į latvio konceptą žiūrima iš apačios į viršų (angl. „,bottom-up“ approach, plg. Tissari 2008): latvis aptariamas derinant struktūrinị požiūrị i reikšmę su kognityviniu. Laikomasi nuomonès, kad ,struktūrinė reikšmè yra eksplikuota kognityvinè reikšmé“ (Jakaitienė 1988: 58; plg. Jakaitienė 2010: 56; Gudavičius 2011: 117). Struktūrinè reikšmè su konceptu susijusi dalies ir visumos santykiu sąlygiškai, t. y. ji verbalizuoja tam tikrus kintančius mentalinio turinio elementus. Einama nuo žodžio reikšmės kaip kalbos vieneto turinio, atsirandančio iš žinojimo, kas pavadinama tuo kalbos vienetu, analizuojami žodžių tarpusavio santykiai sakinyje ir žiūrima, kokia informacija jais komunikuojama - sakinio prasmè (plg. Jakaitienè 1988: 42t; 2010, 17t, 45t, 50; Gudavičius 2011: 117). Remiantis tuo, paaiškejja tam tikra

10 Apie terminų reikšmé, sq̨voka, konceptas ir prasmè turinį ir jų tarpusavio ryšius plačiau žr. Gudavičius (2011; 2007: 14tt), plg. Jakaitienè (2010: 46tt).

${ }^{11}$ DLKT publicistikos pagrindu nagrinètas ir lenkès paveikslas. Plačiau žr. Čižik-Prokaševa (2020).

12 „Aprašant kalbos vartoseną, kuri nuolat kinta ir todèl labai sunku ją nustatyti (apibrèžti), galima operuoti tik tendencijomis“" (Vykepĕl 2005: 20).

13 Apie latvio autostereotipą žr. Ryžakova, Zavijalova (2008: 33tt, 51t); Boldāne (2014: 145tt ir ten cituojamą literatūrą).

14 Apie latvio požiūrị ị lietuvị žr. Boldāne (2014: 149t). 
tikrovės interpretacija kalboje (plačiau žr. Gudavičius 2007: 10; 2009: 11tt; Rutkovska, Smetona, Smetonienė 2017: 20t, 29 ir ten cituojamą literatūrą).

Šiam straipsniui tiriamoji medžiaga rinkta iš Vytauto Didžiojo universiteto Kompiuterinès lingvistikos centre sudaryto Dabartinès lietuvių kalbos tekstyno (toliau - DLKT ${ }^{15}$ ). Sakiniai atrinkti ị DLKT išplèstinès paieškos laukeli ịrašius žodžio pradžią latv ir pažymèjus varnele analizuoti publicistiką. Naudotas paieškos kriterijus prasideda. Pagal tokią užklausą, kaip matyti 1 lentelejje, DLKT teike beveik 6500 pavartojimo atvejų. Iš jų paeiliui peržiūrejjus per 1000 tyrimui su minimaliu kontekstu (300 ženklų pagal DLKT konkordanso eilutès plotị) paimta 250 iliustracinių pavyzdžių su vyriškosios ir moteriškosios giminès, skirtingų skaičių ir linksnių daiktavardžio latvis formomis.

1 lentele

Skirtingos daiktavardžio latvis, latve formos DLKT publicistikoje

\begin{tabular}{|c|c|c|c|c|c|}
\hline $\begin{array}{c}\text { Tekstyno } \\
\text { dalis }\end{array}$ & Užklausa & $\begin{array}{c}\text { Pavartojimo } \\
\text { skaičius }\end{array}$ & $\begin{array}{c}\text { Bendras } \\
\text { pavartojimo } \\
\text { skaičius }\end{array}$ & $\begin{array}{l}\text { Analizuojamy } \\
\text { šaltinių žodžiu } \\
\text { skaičius }\end{array}$ & $\begin{array}{l}\text { Iš viso } \\
\text { žodžiu }\end{array}$ \\
\hline \multirow[t]{2}{*}{ Publicistika } & $\begin{array}{l}\text { latve } \\
\text { latvei } \\
\text { latves } \\
\text { latvi } \\
\text { latviai } \\
\text { latviais } \\
\text { latviams } \\
\text { latvio } \\
\text { latvis } \\
\text { latviu } \\
\text { latviui } \\
\text { latvius } \\
\text { latvių } \\
\text { latvè } \\
\text { latvėmis } \\
\text { latvėms } \\
\text { latvès } \\
\text { latvę } \\
\text { latvị }\end{array}$ & $\begin{array}{l} \\
6 \\
3 \\
1 \\
1619 \\
347 \\
321 \\
106 \\
401 \\
34 \\
36 \\
269 \\
3179 \\
58 \\
2 \\
6 \\
41 \\
9 \\
52\end{array}$ & 6494 & 48132725 & 86497837 \\
\hline & Iš viso & 6494 & 6494 & 48132725 & 140921288 \\
\hline
\end{tabular}

${ }_{15}$ Prieiga internete: http://tekstynas.vdu.lt. Pavyzdžiai straipsniui rinkti 2021 m. sausio mènesị. 


\section{Latvio apibrèžtis žodynuose}

Norint kalbèti apie tai, kas pasakyta apie latvị DLKT, ir laikantis požiūrio, kad bendroji žodžio reikšmè suvokiama intuityviai, yra abstrakcija (Karaliūnas 1997: 277t), svarbu žinoti, kaip šis daiktavardis apibrèžtas aiškinamuosiuose lietuvių kalbos žodynuose.

Bendrinès lietuvių kalbos žodyne $\left(\mathrm{BLKŽ}_{\mathrm{e}}\right)$ matyti, kad daiktavardis latvis, $-\dot{e}$ - tai „latvių tautos žmogus“. Didžiajame Lietuvių kalbos žodyne ${ }^{16}\left(\mathrm{LKŽ}_{\mathrm{e}}\right)$ latvis teikiamas kaip BLKŽ . Dabartinès lietuvių kalbos žodyne (DLKŽe $)$ atskiro latvis straipsnio nėra. Šis daiktavardis yra žodyniniame latviai straipsnyje: latviai - tai „tauta, gyvenanti Latvijoje, kalbanti viena baltų kalbų“, o latvis „tos tautos žmogus“. Panašiai daiktavardis latviai apibrèžiamas ir BLKŽ („,tauta, gyvenanti Latvijoje, kalbanti viena rytų baltų kalbų“), ir LKŽe (,tauta, gyvenanti Latvijoje ir kalbanti baltų kilmès kalba“).

Iš žodyninių apibrèžčių matyti, kad svarbiausia yra latvio etninė, kalbinẻ ir teritorine tapatybe ${ }^{17}$, o straipsniuose parinkti pavyzdžiai pasako ne tik tai (žr. 1-2 sakinius), bet ir, kad latvis yra darbštus (žr. 3 sakinị), kūrybingas menininkas ir lietuvis jam simpatizuoja (žr. 4 sakinị), su juo kartu gyvena (žr. 5 sakini), bendrauja, bendradarbiauja (žr. 5-7 sakinius).

1) Latviu kalba. BLKŽ

2) Daug amžiu latviai, kaip ir kitos Pabaltijo tautos, buvo tiktai etnine squvoka ir savo šalies valdyme visiškai nedalyvavo $\mathrm{sp}$. LKŽ

3) O, darbštu vyrą, auksinių nagų latvi gavo Krš. LKŽ

4) Ši latvé dailininke man labai patinka. BLKŽ

5) Mes su tais latviais kartu augom, kartu banda ganèm Škn. LKŽ

6) Studiju metais susirašinëjau su vi enu latviu. BLKŽ

7) Futbolo klubas pasirašè sutarti su latviu. BLKŽ

Žodynų pavyzdžiuose aktualizuota ir bendra - baltiška - latvio ir lietuvio kilmè (žr. 8-9 sakinius). Tai ir reziumuotuose darbuose (žr. 1 skirsnị) minètas lietuvio ir latvio panašumas duoda pagrindo ị latvị žiūrèti ir biologiniu - giminès, arba plačiai suprantamos šeimos, aspektu ${ }^{18}$. O pastarasis suponuoja glaudžius tarpusavio santykius ir tvirtina minėtą latvio kaip artimo sampratą.

16 Septintasis Lietuvių kalbos žodyno tomas, apimantis L-mèlti, buvo išleistas 1966 metais.

17 Sąvokos kalba, tauta, valstybẻ ,yra taip stipriai susijusios, jog sudaro vienį mūsų sąmonèje: kai kalbama apie kalbq, šalia atsiduria tauta ir valstybe, kai kalbama apie tauta, visada šalia kalba ir valstybë“ (Smetonienè, Smetona, Rutkovska 2019: 7t).

${ }_{18} \mathrm{Plg}$. „Sava sieta su prigimtiniu. [...] [A]smens priklausymą tautai lemia jo kilmė, tautą sudaro ne tik konkrečiu momentu gyvenantieji, bet ir ju protèviai, ir visus narius sieja giminystès, arba kraujo, ryšiai“ (Savoniakaite 2014: 12). 
8) Su lietuviais latvius sieja bendra etninè ir kalbinè kilmè. BLKŽ

9) Lietuvių ir latvių kalba yra išriedëjusi iš labai artimų viena kitai tarmiu K. Būg. LKŽ

\section{Latvis DLKT sakiniuose}

Kristina Rutkovska (2017b: 118), remdamasi kitais autoriais, rašo, kad ,šeima - yra tautos buveine““, o nagrinėdama šeimos konceptą teigia (t. p.: 121), kad ,žodžių šeimyna, gimine definicijos [žodynuose] rodo, kad jie susiję su siaurai suprantama šeimos sąvoka, bet kita vertus, akivaizdu, kad ị šeimą linkstama žiūrèti kaip ị bendruomenę, kurią vienija ne tik kraujo ryšys, bet ir bendri interesai, priklausymas didesnei socialinei grupei ir visai tautai, net žmonių kartai“. Be viso to, eilinio Lietuvos gyventojo supratimu, šeimą taip pat jungia „,kartu atliekami darbai, dvasingumas, o šeimos nariais gali tapti ir dvasiškai artimi žmonès" (Rutkovska 2017b: 148) ${ }^{19}$.

Tai, kad biologiniu aspektu latvis lietuvio suvokiamas kaip tos pačios, savos (baltų) giminès, šeimos narys, rodo 10-13 sakiniai. Čia latvis įvardijamas kaip brolis ${ }^{20}$ ar sesuo ${ }^{21}$. Tokia žiūra leidžia suabejoti reziumuotuose darbuose (žr. 1 skirsnị) išsakyta mintimi, kad lietuvis mažai pažista latvị, ir manyti kitaip: kad jau lietuvis latvi mato šeimos nariu, artimuoju, jis pažista jị ganètinai ir būtent tai turi ịtakos jau minètam latvio kaip savo, artimo, suvokimui. Marius Smetona (2019a: 29), remdamasis Anthoniu Smithu (1994: 7tt), rašo, kad „neįmanoma įdiegti žmonėms giminystės ir brolybès jausmo nesiejant ju su vieta, kurią jie jaučia esant sava“. Neveltui latvis lietuvio įvardijamas kaip artimiausias - tiek vietos, tiek glaudaus, artimo, ryšio aspektu (žr. 14-15 sakinius). Tai, kad latvis gerai pažįstamas artimasis, rodo ir 16-19 sakiniai, kur jis vadinamas draugu ${ }^{22}$ arba mūsiškiu. Tokia istoriškai susiformavusi lietuvio žiūra ị latvị suponuoja abipusiškumu paremtą artumą ir pamatinę tarpusavio santykių nuostatą - iš meilès kylantị palankumą (plg. Rutkovska 2017b: 129; Vaičiulytė-Semėnienė 2020: 360; plg. 4, 20 sakinius) ${ }^{23}$.

19 Apie semantinę šeimos ir žmogaus sąsają žr. Sakalauskienė (2018: 177, 183).

${ }^{20} \mathrm{Plg}$. DLKŽ $\check{\mathrm{e}}_{\mathrm{e}}$ brolis - 1. vyriškosios lyties žmogus kitiems savo tévų vaikams; 3 . prk. tos pačios aplinkos, bendrų interesų vyras; artimas, bendras, bičiulis, draugas.

21 Plg. DLKŽ $\check{e}_{\mathrm{e}}$ : sesuo - 1. moteriškosios lyties žmogus kitiems savo tėvų vaikams; 2. prk. tos pačios aplinkos, bendru interesų moteris, bičiulè.

22 Plačiau apie drauga žr. Vaičiulytė-Semėnienè (2020).

${ }^{23} \mathrm{Plg}$. „[L]atyšskie respondenty projavili bol'šuju lojal'nost' po otnošeniju k «čužomu» miru” (Ryžakova, Zav'jalova 2008: 155); bolšuju gotovnost' „prinjat' ego v kategoriju «svoego»“ (Ryžakova, Zavijalova 2008: 158). 
10) Lietuviai ir latviai yra tarsi broliai, seserys - giminès.

11) Lietuviai ir latviai - broliškos tautos, mus sieja genetinis ryšys, baltiškas mentalitetas, pasaulëjauta.

12) Mokslas aiškina, kad iš visu kada nors gyvenusių baltu genčiu iki šiol išliko tik dvi - lietuviai ir latviai. Taigi slavu apsuptyje turetume džiaugtis turédami artima genti, brolius, seseris.

13) Ir kartais atrodo, kad jau 4000 metu prie Baltijos jūros gyvendami kartu su broliais latviais vis dar pamename savo baltiškosios dvasios bei kultūros ištakas. Vis dar šaukiame tais pačiais žodžiais Jūrą, Žemę, Motina, Saulę...24

14) Pirmiausia jų [tarptautinių meninių ryšių] ieškota su artimiausiais ir palankiausiai nusiteikusias kaimynais - latviais.

15) Lenkai - išdidūs, spekuliantai ir sukčiai, o žydai vieniems - sukti, gudrūs ir apgavikai, kitiems - geri žmonès. Artimiausi lietuviams žmonès - latviai, kurie yra lyg broliai. Estai - išdidūs ir šalti, nors geri žmonès.

16) Mes prisimineme latvị Talivaldị, ieškantị ir radusị Lietuvoje brolių, o ne priešų.

17) Keista ir juokinga. Latviai, mūsų broliu tauta, to pačio likimo draugai - šiandien mus savo žemëje su automatais saugo.

18) Nepaminèti, kad tūkstančiai mūsiškiu - ir latvių, ir lietuvių - geresnio gyvenimo ieškoti priversti išvykti iš šalies, yra nusikaltimas.

19) Jos [iš viršaus siūlomos malonès] negarantuoja mūsu - paskutiniu (kartu su latviais) baltų išlikimo.

20) Latve trumpam atsigavo nuo veriančiu žvilgsnių. Nors atrodè lyg fifočka - gražiu veido bruožų, lieknos figūros, tačiau nuo jos sklido šiluma.

Be to, kad lietuvis latvị ir, panašu, atvirkščiai ${ }^{25}$ mato kaip artimą, ir kiti, svetim(esn)i, ị juos žiūri kaip ị vienị:

21) Kas ten tavo poligone krepšinị žaidžia? Aš nieko nesuprantu, tyliu, o paskui sakau: lietuvis... ir latvis. Geri kareiviai. O jis juokiasi: „Taip ir žinojau... Tuos pribaltus nuvešk ị negyvenamają salą, pirmiausiai jie pasistatys krepši, o tik po to pastogę.

${ }^{24}$ Dar plg. DLKT sakinį: Veike Vyriausiasis Lietuviu Tautos komitetas, kuris pasisakè už daugiatautès valstybès sukūrimq. Pagal jo projektq, lietuviai kartu su latviais ir gudais turètu atkurti LDK. Tautas vienytų monarchija, visos trys tautos šioje valstybëje turètu autonomiją.

25 Plg. DLKT sakinị: Tačiau, manau, tai tèra draugiški pasišaipymai. Lietuviams esame artimesni nei estams, kurie kultūrine ir kalbine prasme nèra baltai. Tiesa, latvių kalba yra patyrusi tam tikra estų kalbos ịtakq - mūsų kalbininkai juokauja, kad latvių kalba yra ne kas kita, kaip netaisyklinga lietuviu kalba. 
Nelabai skiria, kas kaip šneka, tai ị kakta gali gauti bet kuris Baltijos šaliu pilietis. Ir visais atvejais smurtininkai paaiškins, kad muša ne veltui. Latvis gaus už tai, kad Latvijoje neva pažeidžiamos rusakalbiu teisès, o lietuvis - „dèl kompanijos“.

Šeimai, draugams būdingos vienio ${ }^{26}$ pajautos nuostata aktualizuojama ir 22-23 sakiniuose, kur latvių visuomenè arba Pabaltijys gali būti suprantama kaip šeima.

22) Palyginimai Baltijos šalyse gana taikliai atspindi situaciją regione: estai eina $\mathfrak{i}$ Vakarus, lietuviai nacionalistiškai didžiuojasi savo imperija, o latviai susirūpinę dèl visuomenès pasidalinimo.

23) Petys $i$ peti. vieningomis pastangomis stengsis ịsitvirtinti po Europos saule [...]; lietuvis, latvis ir estas, susitikę kur nors užsienyje, puls vienas kitam i glèbi, bet kurioje diskusijoje sudarys viena frontą.

Žinoma, kad ir kiek latvis ir lietuvis yra artimi (žr. 24 sakini), konstatuotina ir tai, kad kiekvienas jų, kaip ir atskiras žmogus šeimoje, turi savitumo, bendraujant darančio ịtakos kito savivokai ir nuostatoms (žr. 25-26 sakinius).

24) Be to, mūsu komerciniai kanalai, švelniai tariant, nuobodūs visomis prasmémis. Bet tą pati galima pasakyti ir apie jų bendraamžius latvius bei estus.

25) Neretai apstulbina mentaliteto skirtumai. Kartais negali ne įsivaizduoti, kad problemu gali kilti, lietuvio akimis žiürint, lygioje vietoje. Latvis su latviu geriau susitars nei lietuvis su latviu.

26) S. Gedos, M. Martinaičio ir kitu poetiniam pasaulèvaizdžiui formuotis buvo be galo svarbi latviu tautiniu dainu pasaulejauta. Visa tai buvo jungtys, kurios palaikè mūsų tautas ir kultūras, mūsų gyvybinę galiq ištisus šimtmečius ${ }^{27}$.

Lietuvio žiūra ị latvị kaip ị plačiai suvokiamos vienos, bendrus protėvius turinčios šeimos narį ${ }^{28}$, draugą duoda pagrindo latvio paveikslą plètoti semantiniu šeimos ${ }^{29}$, žmogaus pagrindu: ne tik jau minètu biologiniu, bet ir (psicho)socialiniu, psichologiniu, fiziniu, buitiniu, lokaliniu, religiniu aspektu.

${ }_{26}$ Plg. „Iš esmès tauta - tai nedalomas vienetas, kuris asocijuojasi su namais ar šeima. Pagrindinis siejantis žodis yra vienybë“ (Smetonienė 2019: 174).

27 Plg. dar DLKT sakinị: Mano pasakos lietuviu kalba bus mano širdies kelionè ị brolių tautos žemę. Mes nesame svetimi. Lietuvių ir latvių dainu gèle senovejje pražydo po bendru šventuoju ąžuolu, vienos sielos sauleje.

28 Apie jaunimo požiūrị ir tautos ir šeimos suvokimo sąsają žr. Smetona (2019b: 84tt). Apie tai, kad tauta asocijuojasi su namais ar šeima ir tautą gali sudaryti ne tik vienas, bet ir keli giminingi etnosai, žr. Smetonienè (2019: 174t).

29 Apie semantinius šeimos aspektus plačiau žr. Rutkovska (2017b: 145tt). 
Socialinis aspektas apima pavyzdžius, kur pasakoma apie latvio santykius su žmonėmis, bendradarbiavimą ir pagalbą. Padèti kitam - ịprasta latviui, kartais rizikuojant savo saugumu. Jis su meile ir atjauta palaiko, padeda tautiečiams ir krašto kaimynams, dovanai dalinasi savo žiniomis, gebejiimais, užgyventu turtu - tuo, kuo gali, ką turi (žr. 27-33 sakinius). Latvis visų savų labui geba atsisakyti asmeninès naudos (žr. 34 sakinị).

27) Kadangi buvau išaukletas latviška dvasia ir jaučiuosi esąs latvis, tai, savaime suprantama, pirmiausia stengiausi padeti Latvijai, kol buvo paskirtas pirmasis Latvijos ambasadorius, buvau net igaliotas jos atstovas.

28) Ne visose šeimose kalbama latviškai, o čia vaikams yra proga išgirsti savo gimtają kalbą. Latvijos ambasada Lietuvoje finansiškai remia ivairius latviu klubus, draugijas, organizuoja ekskursijas.

29) IAV lietuvių talka Lietuvos ambasadai Vašingtone sovietmečiu Lietuvos ambasada Vašingtone sovietmečiu gelbejo ne tik broliai latviai, bet ir JAV gyvenantieji lietuviai, kurie gausiai aukojo ambasados remonto darbams. Susitarta su latviais, kad jie padès išlaikyti Lietuvos pasiuntinybę Vašingtone. Ir toks palaikymas truko iki pat 1990 m. vidurio.

30) Gyvensi, jau dabar gyvensi, - kalbëjo jam latvis. Taip jie susipažino. Gaila, nežinoma gerojo latvio pavardè [...]. Slaugè latvis Broniu beveik tris menesius, išslauge tiek, kad šis jau ir po namus paslankioti èmé.

31) Mokytojoms lietuvèms šauniai talkina latvès.

32) Dantytas pyragaitis su skyle vidury - 10 kapeikų. Šiltas pyragaitis 6 kapeikos. Tu kapeiku tada neturejjau, todèl prisimenu ir varda, pavardę latvio, kuris, pats būdamas ne ka turtingesnis ir tikrai ne sotesnis, paskolino 15 kapeiku.

33) Nuveže 12 km nuo Laižuvos ị kažkokị latvių kaimą. Ten mus iškrove pamiškejj ir paliko. Mama su teta nuëjo ieškoti pas ūkininkus kokio kambario, bet nieko nerado. Tik vienas latvis - turtingas, nors namas didžiulis ir tuščias, leido mums apsigyventi dūminëje pirtyje prie miško ir mažo upelio.

34) Perkaitima išgyvenančios kaimyninès Latvijos vyriausybė sugebëjo atsispirti išlaidavimo pagundoms ir patvirtino 2008-uju perteklini biudžetą.

Latviai ryžosi įšaldyti valdininku algas ir taip pažaboti infliacija.

Lankstus situacijoje, kito gyvenimu besidomintis ir iš kito besimokantis latvis (žr. 35-37 sakinius) bendradarbiauja švietimo, mokslo, kultūros, politikos, krašto gynybos klausimais (žr. 14, 38-42 sakinius), o gebejjimas susitarti, ieškoti kompromisų, bendri interesai ir kartu atliekami darbai ir tikslai suvienija latvị ir lietuvị (žr. 43-45, plg. 41 sakinius). Tokios savybès būdingos ir 
siaurai suvokiamai šeimai, kur svarbu „,mokèjimas sutarti, nusileisti, išklausyti ir patarti. Kitų interesai turi būti tokie pat svarbūs kaip asmeniniai, ir net svarbesni. Tai ne tik psichologinis pritapimas, bet ir svarbus socialinis, buitinis santykių suderinamumas“ (Rutkovska 2017b: 139; dar žr. 126).

35) Latvis, pvz., yra stipresnès technikinès kultūros ir stipresnio oportunizmo (prisitaikymo). Emigracijoje lietuvis išliks ilgiau savitas, latvis greičiau prisitaikys. Lietuvis jausis naujam gyvenimui ilgiau svetimas, latvis i ji lengviau įsilies ir greičiau bus patenkintas.

36) Latviai ir estai, pasimokę iš mūsų klaidų, pirmiausia kuria bendrijas ir tik po to privatizuoja butus.

37) Tada ir po olimpiados mes kvietème latvius atvažiuoti j Kempteną, dar ten sužaisti rungtynes, bet latviai atsisake, kartu pritardami, kad amerikiečiu zonoje jie labiau norètu pažaisti su jų karių komandomis, galètú daugiau pasitobulinti.

38) Lietuvių studentų draugija per latvị studentq̨ medikq P. Kalninị užmezgé ryšius su latvių studentų draugija.

39) Vytauto Didžiojo universitete sèkmingai gyvuoja Letonikos centras, kuriame dirbantys mokslininkai kartu su kolegomis latviais leidžia mokslo leidini „Acta Baltica 2001“.

40) Priežastys, kodèl „Nereikalingi žmonès“ yra daugiau nei vien tik lietuviškas filmas, yra kelios: marga kūrëjų komanda - režisierius ir scenarijaus autorius latvis Maris Martinsonas, operatorius Gintas Berzinis, lietuviu ir latviu prodiuseriai.

41) Politiškai visq laikq veikème kartu su latviais ir estais kaip tam tikras geografinis vienetas. Dabar linkstama veikti atskirai, nes iškyla tam tikru skirtumu nepriklausomybę atgavusiose Baltijos valstybèse.

42) İdomus P. G. pateiktas Kiemènu kautynių, kur „kovojo drauge lietuviai ir latviai su bendru priešu ir atnaujino senaji broliu tautu ginklu draugavima", aprašymas.

43) Greit po šio mitingo vyko akcijos: Baltijos jūros ,,apkabinimas rankomis“ (0903 kartu su latviais, dalyvavo apie 100 tūkst. žmoniu), Ignalinos atominès elektrinès „apjuosimas gyvybès žiedu“ (09 16-17).

44) Zarasuose liks muitinès skyrius. Numatoma Smèlynès poste dirbti kartu su Latvijos muitininkais vienoje patalpoje. Tokiam sumanymui latviai neprieštarauja ir tai būtų naudinga visapusiškai. Vietoje dvieju būtu vienas tikrinimas, mažiau laiko sugaištu transporto vairuotojai ir keleiviai.

45) Bandèm laikytis senosios sienos ribu, tačiau neįmanoma išvengti smulkiu pokyčių. Kartu su latviais ieškojome kompromisų. Kai kuriose 
vietose lietuviai pasistūmèdavo Latvijos pusèn, o kitose - atvirkščiai, pasakojo Aerogeodezijos instituto direktorius.

Tai, kad, nepaisant nuoskriaudų, pykčio, ginčų, nesutarimų, skirtingų nuomonių, pasitaikančių ir šeimoje, latviui svarbu artumas ir solidarumas ne tik su sav(esni)ais, bet ir su svetim(esni)ais, rodo 16, 46-49 sakiniai. Šiuc nuostatu pagrindu vienas kitą atliepiantys, norintys ir gebantys vienas kitą suprasti - sav(esn)i, artim(esn)i, tautu atstovai tampa draugais, kuria siaurai suprantamą šeimą (žr. 50 sakini).

46) Latviai - gal ir broliai, tačiau, kaip ir kiekvienoje šeimoje, nuolat randame, už ka jiems priekaištauti.

47) Niekas negalëjo pagalvoti, kad tiek problemu iškils tariantis su broliais latviais. Ir dèl ko? Dèl jūros sienos. Jau bene 6 metai apie tai kalbame, ginčijamès, vos i atlapus nekimbam. Kartais, rodos, tuoj tuoj bus susitarta.

48) Praëjo ne tiek jau daug metų, ir su „broliais latviais“ juyko ne vienas aštrus susikirtimas, pasigirdo abipusiu įžeidinëjimu.

49) Vokiečiu tautines mažumos atstovams Latvijos parlamente syki net buvo pavesta suformuoti vyriausybę. Patys vokiečiai tuo labai stebëjosi - kaipgi latviai, 700 metu kente vokiečiu priespauda, jiems nekerštauja, o sutinka juos vèl matyti savo valdžioje. Vokietijos spauda rašè, kad šitokio kilnaus latviu poelgio vokiečiai nepamirš per amžius.

50) Prisiglaude grịž̨ iš Sibiro, Lietuvoje nesuradę galimybiu prisiregistruoti ir gauti darba, kiti kèlèsi ị Latviją dèl šeimyninių aplinkybių: pas vyra latvị ar pas latvę žmoną,

Iš pavyzdžių aiškèja, kad latvis gero (pra)gyvenimo rezultato, (bendrų) tikslų (plg. 51-53 sakinius) siekia dvejopai: veikdamas lètai, apgalvotai, patikimai ir užtikrintai (žr. 54-56 sakinius), bet gali be baimès rizikuoti, veikti spontaniškai, azartiškai, ryžtingai, greitai, energingai (žr. 57-58 sakinius).

51) Kiekvienam latviui prieš metus teko 144 doleriai investiciju. O Lietuvoje (šiemet kovo mènesi) galëjome girtis tik 65 JAV doleriais vienam gyventojui.

52) Kone kiekvienas latvis važinëjo nauju automobiliu.

53) Latviu vadovybei paprašius, Pasvalio partizanai lapkričio 12 diena iš pietu pusès puole Bauskę, padedami latviams išvaduoti miestą, o vèliau kartu su latviais išvijo priešą iš Žeimelio ir Kriūkų.

54) Lietuvis neretai stačia galva puola veikti, o paskui taiso ir perdarinëja, o latviai paprastai taip nesielgia. Latvis verslininkas geriau mažiau parduos, bet brangiau, ir nesidraskys kaip lietuvis. 
55) Nebuvo viskas perkūnais trankoma, žaibais deginama. Latviai, ypač estai, geriau už mus sau pritaike lietuviška posakį: „Skubos darbq velnias renka"30.

56) Jei šeimininkas Airijoje priima dirbti latvị, jis ramus. Darbininkas atlieka viska, ka palieptas. Ryškiai blyksteleddavo latvio, kaip viensèdininko, būdas - kiekvienas pluša nugaros neištiesdamas.

57) Žiūrèk, antraštè: „Latvija perèmè Mažeikius“. Akimirką būtų laimingi visi: ir ponas Remigijus, besitikis gauti pigesnio benzino, kai latviai imsis darbo, ir nuolat ieškantys, kaip įkandus kaimynui ị kulkšnį, kai naftos tiekimas netyčia sustos, ir patys latviai bus laimingi akimirką. Kita akimirka jie jau galvos: Mažeikius turime, tad beliko rasti naftos.

58) Apie didelius skirtumus Lietuvos ir Latvijos kultūros politikoje kaip tik ir norisi pašnekèti ypatingu valstybiniu švenčiu kontekste. Latviu veržlumas ir lietuvių vizijos ${ }^{31}$.

Kalbant apie latvi psichosocialiniu aspektu, svarbu yra per buvimą ir veikimą kartu, per bendravimą, (susi)kalbejjimą savo kalbomis (žr. 47, 59-60 sakinius) matomas jo požiūris ị kitą žmogų. Lietuvio akimis, latvis yra draugiškas: palankus, dẻkingas, rūpestingas, patikimas, palaikantis, (at) jaučiantis, solidarus, pagarbus (žr. 61-65 sakinius).

59) Prisigeria, ir Navakas, apsikabinęs latvi, šaukia: „Lai dzyvuoj Latvïa!““ Tas rèkia: „I Lietuva, j Lietuvą!"“

60) Pranešéjas išdalijo klausytojams savo tezes latviu kalba, kuriose dèstomi tie patys lakoniškai nusakyti biografiniai faktai, net latviškai nemokančiam lietuviui nesunkiai išsiverčiami ${ }^{32}$.

61) Apèmé jausmas, kad mes viska jau turime - vykusị šeimininka, gera darbq draugiškame latviu kolektyve, šiluma ir jokių skersvëjų.

62) Mano bičiulis latviu poetas K. S. sako: kq aš galiu padèti, tai kentèti sykiu su tavimi. Bet žmogui daugiau nieko ir nereikia, jei jis mato, kad kartu su juo kenčia.

${ }^{30}$ Dar plg. DLKT sakinius: Net 26,9 proc. apklaustųju negalëjo ịvardyti tautos, lètesnès negu lietuviai. Latvius lètesniais už lietuvius dažniau laiko moterys.

Tas pats Karlis, pusamžis lètas latvis, pasakoja apie paskutinị savo vizitą j Maskvą.

${ }^{31}$ Dar plg. DLKT sakinius: Dar keturi tokie objektai projektuojami - Garliavoje, Prienuose, Šilaleje ir Rietave. Jei tokiais tempais judèsime toliau, po 10-15 metu prilygsime latviams, estams.

Nenusileiskime savo žiniomis, ryžtu ir užsispyrimu broliams latviams ir estams.

Lietuvos Prezidentas mano, kad latviai pasikarščiavo.

32 Dar plg. DLKT sakinį: Tačiau ịdomiausia, kad vienas nemokëjo nei lietuviškai, nei rusiškai, nei angliškai. Jis buvo latvis, - sake plk. ltn. R. Zinkevičius. Tačiau posèdžio dalyviams nebuvo paaiškinta, kaip latvis sugebëjo "integruotis" i mūsų kariuomenę. 
63) Ne vienas latvis ir estas, tartum nustebę dèl netikèto jų nepriklausomybès pripažinimo šį rudeni, pasakydavo: ačiū Lietuvai, tai Lietuva visas tris drauge išvedè.

64) Su manimi kalba latvis - linksmai, palaikomai ir neatstumdamas.

65) Latvijoje taip pat, latviai gerbia lietuvius, tačiau kalbant apie tai reikia išskirti dvi problemos puses. Pirma, latviai lietuviams yra palankūs.

DLKT pavyzdžiai leidžia kalbèti ir apie šeimos (psicho)socialinį stereotipą neatitinkantị latvị, kuris yra nepatiklus, šaltas, uždaras (žr. 66-68 sakinius).

66) Vairuotojas su nepažistamuoju buvo sustojęs Kaune. Vyrai vienoje kavinëje papietavo ir pasuko Marijampolès link. Latvis netikëjo plepalais. Latvis skeptiškai vertino šnekaus pakeleivio riečiamas istorijas, tačiau garsiai abejoniu nereiškè.

67) Kai mes kq nors cyptelime, tik slapčiomis iš padilbu žvairuoja kažkur ị šona, apnuogindamas dvieju pirštų siaurumo kaktą. Latviai taip daro. Kai latvis nesijaučia saugus, jis užsidaro, tarsi tvenkinys apsitraukia ledu.

68) Publika Lietuvoje visada buvo gera ir šilta; pavyzdžiui, latvių publika šaltesne.

Latvis gali būti ir nepatikimas, pašaipus, šmeižikas, dvilypis, savanaudis, išdavikas, pretenzingas, užsispyrusiai besilaikantis savo nuomonès, melagis, suktas:

69) Čia latviui liežuvis atsirišo ir kad pradès girtis: - ... Mūsų šalyje ir pragyvenimo lygis, ir atlyginimai, ir nafta... O jūs, lietuviai, nieko gero neturite.

70) Dar prieš Pirmaji pasaulinị karą latviu rašytojas A. U. pastebëjo viena labai keistą reiškinị ir smagiai pasišaipe: „Prastas yra tas lietuvis, kuris nenori büti lenku“.

71) Antro argumento esmè buvo ta, kad bolševikais negalima pasitikèti, nes jie laužo sutartis. Ir trečiasis - negalima pasitikèti ir latviais, nes jie gali susitarti su lenkais.

72) Po tokio Vilniaus apskrities valdytojo poelgio tampa aišku, kodèl [...] latviai mus vedžioja už nosies jau daugiau kaip metai.

73) Latviai mus puola, o mes leidžiam tai daryti. Aš buvau apšmeižta, tačiau latviai dèl to neatsiprašé.

74) Nepaisant aukščiau minimų dalykų, latviai veikiausiai ir toliau bus, švelniai tariant, pragmatiški - jiems tai labai naudinga.

75) Galima sutarties su „Amoco“ ir OPAB ratifikavima Latvijos parlamente Lietuvos diplomatai dokumente vertina kaip vienašališka latviu pretenzija ì Lietuvos šelfo dalỉ ${ }^{33}$.

${ }^{33}$ Dar plg. DLKT sakinį: Be to, su broliais latviais galime ir susipykti. Kaip ir dèl naftos klodų Baltijoje... 
76) Jeigu išplëšiamos sodybos, per žiemą išardomos krosnys, visos gèrybès atrandamos šio latvio sodyboje.

Psichinį, psichologini aspektą apima pavyzdžiai, kur ịvardijami latvio jausmai, emocijos, dvasinis pasaulis, pojūčiai, pomégiai. Pavyzdžiui, pasakoma, kad latvis žaidžia krepšinį, mėgsta muzikuoti, motorlaivius, vandens motociklus (žr. 21, 77-78 sakinius).

77) Čia atvyksta ir broliai latviai - gurkštelti alaus, pamuzikuoti, pasisemti patirties. Šiauliai yra muzikantų miestas. Šia prasme jis kažkuo panašus j susibroliavusị miestą Jelgava.

78) Pasaulio čempionate debiutavęs lietuvis atstovavo Latvijos komandai „Vivid“, kurioje lenktyniauja ir V. K. Anot kauniečio, su latviu motorlaivininkais jis bendradarbiauja daugiau nei 20 metu.

Latvis myli savo tèvynę ir tautą (žr. 79-80, plg. 20 sakini). Jis nori būti nepriklausomas ir nepriklausomybę brangina, ja didžiuojasi (žr. 8082 sakinius) $)^{34}$. Todèl saugo, gina savo, artimo kraštą ir jo gyventojus nuo užpuolikų (žr. 83-84 sakinius), kita vertus, gali turèti teritorinių pretenziju (žr. 85 sakinị).

79) Savo Tèvynę myli ir latviai.

80) V. L. buvo tikras latvis, geras latvis. Jis mylëjo išdidžiq latviu tautq, jos garbei krove Stalino ir kitokias premijas.

81) Latvijos ambasados kultūros atašè Elita Gavele sakè, kad Nepriklausomybès diena brangi ir tiems latviams, kurie gyvena tévynëje, ir tiems, kurie Lietuvoje.

82) Artimiausi mūsų kaimynai latviai, kurie, prisimindami 1990-uju Latvijos Nepriklausomybès paskelbimo metiniu proga, nusprendè apie ja priminti ne tik visai tautai, bet ir pasauliui.

83) Latvių kariuomené sumušè vokiečius ties Dauguva, atstūmè juos nuo Rygos ir lapkričio $17 d$. jau buvo netoli Mintaujos.

84) „Aš, latvis Liepis, išperku savo kaltę okupuotai latvių ir lietuvių tautai...“ Liepis liko pas partizanus. Juozui [...] dar karta likimas lèmé išlikti.

85) 1920 m. buvo nesureguliuota ne tik rytuose, bet ir šiaureje. Su Latvija tebevyko ginčai dèl Palangos, Mažeikiu, Alukštos apskričių. Tarp lietuviu ir latviu kariuomenès daliniu ịvyko net susišaudymu.

${ }^{34}$ Plg. latvio autostereotipą: „Dlja latyšej, v otličie ot vseh drugih oprašivaemyh, bolee svjaščennymi okazalis' simvoly gosudarstvennosti i nezavisimosti“ (Ryžakova, Zavijalova 2008: 152). 
Latvis, lietuvio akimis, yra doras, ramus, padorus, kuklus, mąslus, gudrus, jaučiantis savo vertę (žr. 86-89, plg. 69, 101 sakinius).

86) Jo tèvas buvo ateivis, latvis, ịsikūręs pamiškejje tarp Rumpiškènu ir Latveliu kaimu, žmogus ramus ir padorus.

87) Latviai ramesni, labiau apmąstantys ir pasveriantys.

88) Batalionai nepilnos sudèties. Latviai kuklesni. Kai j. ltn. Uldị Davidovq paklausiau, kodèl jie batalionus vadina šaulių, o ne motošauliu vardu, tas tik ranka numojo: Kokie čia motošauliai.

89) Latvis jokiais būdais nesutiko žemintis.

Latvio ramumas, matyt, gali būti suprantamas ir kaip niūrumas, šaltumas (žr. 90, plg. 68 sakini). O pakankama savivertẻ leidžia latviui jaustis lygiam tarp kitų, drąsiai atstovauti savo teisėms ir interesams (žr. 91 sakinị).

90) Pasigirdus ne angliškam hallo, tokiam optimistiškai pakiliam, bet latviškam pažįstamam niūriam nu-u, man jau nebesvarbu, kq sako vaikinas. Latvis. Mielieji, tipiškas latvis - lyg truputèli paniuręs, žiūrintis iš už kampo, iš pasalų. Toks, kuris nenori, kad trukdytu jam ramybę ir che che jame gali atpažinti molio motiejų.

91) Latviai, girdëjom, streikuoti buvo pratę, darbdaviai ju visados bijoję... Kaip, girdejome, ir latviu prezidentai... - Jeigu norite, kad normaliai dirbtume, prašom normalaus maisto!..

Latvis, lietuvio supratimu, - aistringas, linksmas, švenčiantis gyvenimą (labiau) optimistas (žr. 92-94 sakinius). Tai, kad latvis yra laisvesnių pažiūrų ir mažiau paiso normų, nustatytų taisyklių, reikalavimų, pasakyta ir 95-96 sakiniuose.

92) Mes - puritonai. Bent jau tokiais mus laiko artimiausi kaimynairusai ir latviai, pas kuriuos aistru šèlsmas, atsiskleidžiantis aktyviai veikiančiose sekse klubuose, laikraščiuose, draugijose, pasiekè, manau, kulminacija $q^{35}$.

93) Moteriai nešykštëjo kūno, išvaizdos ir optimistiškos bei linksmos sielos. Ka ji veikia čia, šitame Airijos grybu angare? Kodèl ji nepuošia kokio latvio, stambaus ūkininko, namo? Nesisukinëja tvarte dainuodama, rankomis nemelžia dviejų tuzinų karvių?

${ }_{35}$ Plg. dar DLKT sakinius: Kiti nesupranta jos juoko ir pasiryžimo būti tokia jaudinamai atvira. Trys sédintys vyrai įnikę ị laikraščius. Matyt, jos kolegos. Su savo vyru latvé neleistų sau taip atvirai flirtuoti. Kolegos latviai suprunkščia ị apykakles ir leidžia moteriai dar mégautis laisve. Jei kokia mergužèle airių smuklëje ant stalo šoka, žymekliai apie latves kaip ištvirkèles įšaudomi ir i kitu ausis, kaip vienos bandos veršiams. 
94) Šeštadieninès orgïos atsinaujins! Šeštadieniais po antskrydžio ị prekybos centra mūsų namas tarsi atgyja. Kas daro latvị linksma, jei nèra tikros priežasties linksmintis? Aišku, gerbiamosios ir gerbiamieji, tai maistas!

95) Lietuva stengiasi kaupti strategines atsargas, tuo tarpu latviai dažniausiai nesilaikydavo šio reikalavimo.

96) Jos [Lietuvos lesbietės] nedrista atvirai teigti savo subkultūros, kaip tai daré latvès.

Pasakoma, kad latvis yra iniciatyvus, novatoriškas, kūrybingas, turintis savitą požiūrị ir vertybes, susiformamusius savos kultūros ir tradicijos pagrindu (dar žr. 35 sakinị):

97) One idëinis „krikštatèvis“ buvo latvis Vitalijus Rubšteinas, visada turëjęs ,gyslelę“ novatoriškiems interneto produktams kurti.

98) Rasa Paukštytè: Mes mažai žinom apie latvių teatra ir apie jus. Ar anksčiau büta ko nors panašaus i jūsiškę „Žuveddra“? Kaip toks netikètas požiūris ị Čechovo pjesę buvo prïmtas Latvijoje? Požiūriu su režisierium net negalima polemizuoti, nes jis nuo pradžios iki galo stengesi jitvirtinti šia savo poziciją. Alvis Hermanis: Sukūriau spektakli latviu publikai. Mano žiūrovai - ne festivaline publika ir ne kritikai, o rygiečiai, latviai. Irena Aleksaite: Ar jie kuo nors ypatingi? Alvis Hermanis: Šitas spektaklis turi tam tikra lokalinę erdvę, lokalinị iž̌eminimą.

DLKT pavyzdžiai rodo, kad latviui svarbu garbè, orumas, tikrumas, gimstantis iš meilès ir pagarbos tèvynei, tautai ir tradicijai (žr. 99-100 sakinius). Nuo seno jam reikšminga gamta ${ }^{36}$. Žemé, latvio supratimu, — šventa. Ji visų motina, namai ${ }^{37}$, kuriuos reikia mylèti, puoselèti, auginti, laikyti švarius (žr. 101-104 sakinius). Ši požiūrị atliepia latviui artima žemės spalvų paletė, tiek jo jautrumas, kai / jei žemei ir jos gyventojams (gali būti) kenkiama (žr. 105-107 sakinius).

99) Lietuviai, lyginant su latviais, turi žymiai daugiau teatrališkumo. Latviai esmingesni, užtenka pažiūrèti j jų latus, kad tai suvoktum.

100) Vyrauja literatūrinis mąstymas, spektakliuose nèra jokio komercinio kvapo: pagal matytus pavyzdžius latviu teatra galima pavadinti patriotiniu.

\footnotetext{
${ }^{36}$ Plg. „Dlja litovcev i latyšej bolee svjaščenny i značimy prirodnye ob"ekty i kladbišča” (Ryžakova, Zavíjalova 2008: 152).

37 Plg. ,Namai - tai vieta, kurioje gyvena šeima ir šeimos nariams artimi žmonès, juos sieja dvasinis ryšys. [...] Namus sukurti - tai mokèti sugyventi, gerbti kitus, toleruoti jų poelgius“ (Rutkovska 2017a: 116).
} 
101) Eglyčio lūpomis byloja šimtmečiais išlaikytas latvio savo žemès, savo kertès šventumo suvokimas. Žemè šventa, ir doras žmogus su ja nepražus. Kas tu esi be žemès - kaip vaikas be tèvo ir motinos, benamis.

102) Reikia ja [gamtą] pamylèti, su ja susilieti, jausti taip, kaip ji jaučia, ir ta, ka ji jaučia. Būtent to ir sieke XX a. pradžios lietuviu ir latviu rašytojai, savo kūryba mégine issiklausyti i gamtos paslaptis.

103) Vengrai [stojus gegužès 1-ajai] žada suversti praeities šlamštą ị vienq didelę krūvą, latviai sodins medelius, o štai dievobaimingieji lenkai ta proga raginami nieko neimti i burną.

104) Gal ir teisus buvo latvis, kartq man pasakęs traukinyje, jog Vilnius jam pasirodè esąs ,,didelis, nešvarus kaimas“. Ir tikrai, miela pasivaikščioti Rygoje prie stoties, ten švaru.

105) Man išties labai artimas latviu liaudies menas. Ypač gražūs, išieškoti spalvu perëjimai nuo pilkos iki rudos spalvos.

106) Tad suprantama, jog latviai jautriai reaguoja j̣ ūkio veiklos pokyčius pasienyje, susijusius su galimu poveikiu aplinkai.

107) Neužmiršo brolis latvis ir Karaliaučiaus problemos: ši didžiule Rusijos karine bazé kelia grèsmę regiono saugumui ne vien tiesiogiai, bet ir baseino ekologijai.

Susiformavęs požiūris į žemę galètų būti sietinas su latvio pastovumu, sẻslumu (žr. 108 sakinį), o Baltijos jūra čia pat ji gali daryti spontanišką, dinamišką, judrų (žr. 109 sakinị).

108) Tai šis [latvis] labiau ị kaimietiška sésluma, jausminguma, svajinguma, religinį misticizma, $i$ žemdirbio statiškuma.

109) Kaip jūra ir žemé veikia bei formuoja žmogų ir net ištisas tautas, matyti iš etniniu skirtumu tarp latvio ir lietuvio: kiek anas labiau linkęs $j$ miesteleniška judruma, ì praktiškuma bei pragmatizma, ì prekybq ir pramone, $i$ jūrininkystę, tai šis labiau $i \ldots .$.

DLKT pavyzdžiai patvirtina, kad nuo seno latvis yra linkęs ị mistiką, ritualus, burtininkas (žr. 108, 110 sakinius). Jis domisi savo kraštu, vertina, puoselèja tradicijas, stengiasi jas išlaikyti (žr. 111-113 sakinius).

110) Taigi. Pasakoju ṣ̨̌ tą. O žmonèms ịdomu. Iš latvių išmokau spèti ateitį. Bet šituo menkai tesiverčiu.

111) I ja [ị Rezeknę, ì Joninių šventę] suvažiuoja visi Latvijos folkloriniai ansambliai. Latviai Jonines švenčia daug jausmingiau nei lietuviai, kuriems Joninès - daugiau vardinés. Latvijoje nuo senu laiku pinami ąžuolu vainikai, daromas alus.

112) Be jos [duonos] latviams paprasčiausiai nepadoru palikti Latviją. [...] Tam ši duonelè. Latvès tapatybei patvirtinti. 
113) İdomu tai, kad latviai, restauruodami savo senqsias pilis, atkuria ne tik menes ar kambarius, bet nesibodi rekonstruoti ir ,pikantišku“ detalių: WC karaliams ir tarnams.

Be tų latvių, kuriems svarbu latviška (baltiška) tapatybè ir su ja susijusios vertybès (plg. 111-114 sakinius), esama tokių, kurie dèl vienokių ar kitokių interesų gali to atsisakyti (žr. 115 sakinị), veikti priešingai nei tipiška latviui, kaip šeimos nariui, - išduoti, kenkti (žr. 116-117 sakinius).

114) Panašus j̣ esto prisitaikyma, vis dèlto buvo labiau linkęs dar ir ị atvira kovq už savo tapatybę, už tèvu ir protèviu puoselètas vertybes; gal mažiau kaip latvis buvo linkęs i kompromisus, neskaičiavo krauju, trémimais ir kalëimais skaičiuojamu nuostolių.

115) Ponas R. O. buvo latvis, veliau, paskelbus specialuji dekreta, tapo lietuvis. Sajūdžiui prasidëjus, tapo lietuviu. Dél jo net specialus Lietuvos Aukščiausiosios Tarybos dokumentas buvo surašytas. Tautybe pagal dekreta... Buvo latviu, pasidaré dekretiniu lietuviu, o dabar - i Lietuvos Vyriausybe...

116) Jis [A. V.] kaltinamas latviu tautos genocidu. Būdamas Latvijos SSR vidaus reikaly komisaru, jis sankcionavo masines deportacijas 1941 ir 1949 metais.

117) Štai tau ir išgirtoji latviu vienybe - prieš saviškị, kuris vis dèlto stengiasi išsikapstyti iš pragaro katilo.

Lokalinis aspektas apima pavyzdžius, iš kurių aiškejja, kad latviai, nebūtinai mokantys latvių kalbą, yra plačiai pasklidę po pasaulį: gyvena ne tik Latvijoje, bet ir Lietuvos, Australijos, Amerikos, Rusijos miestuose ir (ar) kaimuose $^{38}$ (žr. 18, 28, 118-120 sakinius).

118) Grupe „Graffiti“ kovo mènesi planuoja pristatyti nauja akustinę programa, o tuo pačiu ir nauja grupés nari - perkusininka, Lietuvoje gyvenantị latvi Jani.

119) Kai kuriais klausimais su lietuviais bendraudavo ir juos palaikydavo Vitebsko gubernijos atstovas, latvis, kunigas Pranciškus Trasūnas.

120) Mat Filadelfijos ir Detroito komandose žaidžia... du latviai, kurie, deja, nemoka latviškai ir né karto nèra buvę savo tèvu gimtinëje. Bet vis vien latviai.

${ }^{38}$ Plg. „Latviai - Europos tauta. Latvijos pagrindiniai gyventojai (1,2 mln. žmonių; 2017), dar gyvena Didžiojoje Britanijoje (apie 102000 žmonių), Jungtinėse Amerikos Valstijose (apie 100000 žmonių), Airijoje (48 000 žmonių), Kanadoje (28 000 žmonių), Vokietijoje (27 700 žmonių), Brazilijoje (25 000 žmonių), Rusijoje (apie 20000 žmonių), Australijoje (19 000 žmonių) ir kitose šalyse. Iš viso pasaulyje yra apie 1,7 mln. latvių“ (Ereminas 2021). 
Fiziniu aspektu apie latvi pasakyta mažai. Turimuose pavyzdžiuose minimas jo ūgis, šypsena ar tiesiog išorinis grožis, apranga (žr. 20, 121-122 sakinị).

121) Pietvakariu suomiams, kurie kartu su švedais laikomi aukščiausiais pasaulyje žmonèmis, ūgiu ne ka nusileidžia vakaru estai ir vakaru latviai. Visi jie - to paties antropologinio tipo. I rytus žmonių ūgis mažeja, o Baltijos finu šviesëja plaukai, oda ir akys.

122) Nedidelio ūgio, meiliai besišypsanti latve Dace Gigele yra vieno iš Latvijos jaunuju ükininku sajungos klubų atsakinga sekretoré.

Ne ką daugiau iš turimų sakinių galima sužinoti apie latvio buitį. Vienur sakoma, kad jis turtingas, kitur - priešingai (žr. 32-33, 123 sakinius). Paminimas Kalèdų valgis, tai, kad latvis geria alų, mègsta pavalgyti (žr. 77, 94, 124 sakini).

123) Latviai neturtingiausi 20050616 Daugiausia ES per metus uždirba britai (36.200 EUR) ir liuksemburgiečiai (35.000 EUR). O mažiausiai latviai - 3.200 EUR, lietuviai 3.400 EUR, estai 4.400 EUR ir slovakai (5.000 EUR).

124) Todèl nebeịmanoma nustatyti lietuvių ir latviu Kūčiu papročiu giminystès. Bendra tarp liuterony ir latviu su lietuviais rytiečiais (AknistosGarsenès apyl.) yra tik Kalèdų išvakarių valgis — su žirniais ar grūdu mišiniu krosnyje troškinta kiaulès galva.

Iš 124-125 sakinių aiškejja, kad, kaip jau minèta ir kitų autorių, religiniu aspektu lietuvis ir latvis skiriasi; pastarasis yra liuteronas. 126 sakinys rodo, kad tai galètų būti pretekstu latvị kiek išstumti iš artimųjų. Tačiau, atsižvelgiant ị tai, kad, kalbant apie šeimą, ,religinis aspektas nėra dominuojantis“ (Rutkovska 2017b: 147), kalbamasis skirtumas nepaneigia esminès lietuvio nuostatos latvio atžvilgiu - jis suvokiamas kaip artimasis, turintis (galintis turèti) tiek teigiamų, tiek neigiamų bruožų.

125) Lietuviai ir lenkai buvo katalikai, žydai - izraelitai, rusai su gudais sentikiai ir stačiatikiai, vokiečiai su latviais - liuteronai ir reformatai, totoriai-mahometonai.

126) Europos pagonims, katalikiškas mentalitetas, matyt, nespëjo taip giliai prigyti, nes nei Biržu, nei Klaipèdos krašte su bambizais nekariavome, ir su latviais-liuteronais nesiriejome - kol netapome laisvi. Nesipešame, bet ir nesibroliaujame.

\section{Apibendrinimas ir išvados}

Išanalizavus 250 DLKT publicistikos sakinių su daiktavardžio latvis skirtingomis formomis, atsiskleidžia ganètinai ịvairiapusis latvio paveikslas. 
Žinoma, iliustraciniai pavyzdžiai visų pirma rodo subjektyvų kalbančiojo, lietuvio, požiūrị, tačiau jų visuma leidžia kalbèti apie gana vientisą latvio koncepto fragmentą.

Atsižvelgus ị ligšioliniuose tyrimuose konstatuotą latvio ir lietuvio panašumą, žodyninius latvio straipsnius, šiame straipsnyje ị latvị žiūrèta semantiniais aspektais. Apie latvị pasakoma biologiniu, (psicho)socialiniu, psichologiniu, buitiniu, fiziniu, lokaliniu, religiniu aspektu. Labiausiai DLKT pavyzdžiuose atsiskleidžia pirmieji trys. Biologiniu aspektu latvis lietuvio suvokiamas kaip vienos šeimos narys - artimasis. Taigi lietuvis latvị pažįsta pakankamai. Tai turi įtakos tam, kad lietuvis mato ir teigiamus, ir neigiamus latvio bruožus, kurių dalis minèta ir ankstesniuose atskirų autorių tyrimuose.

\section{Šaltiniai}

$\mathrm{BLKŽ}_{\mathrm{e}}=$ Bendrinès lietuvių kalbos žodynas: tęstinis elektroninis išteklius, vyr. red. Danutė Liutkevičienè, Vilnius: Lietuvių kalbos institutas, 2013. Prieiga internete: https:// ekalba.lki.lt/bendrines-lietuviu-kalbos-zodynas.

DLKT $=$ Dabartines lietuviu kalbos tekstynas, sud. Kauno Vytauto Didžiojo universiteto Kompiuterinès lingvistikos centras. Prieiga internete: http://donelaitis.vdu.lt.

DLKŽ $\check{\mathrm{e}}_{\mathrm{e}}$ Dabartinés lietuvių kalbos žodynas: 7-as patais. ir papild. leidimas, vyr. red. Stasys Keinys, Vilnius: Lietuvių kalbos institutas, 2012, XXVI, 969 p.; atnaujinta elektroninė versija, 2017. Prieiga internete: https://ekalba.lki.lt/dabartineslietuviu-kalbos-zodynas.

LKŽ $=$ Lietuvių kalbos žodynas (t. I-XX, 1941-2002), redaktorių kolegija: Gertrūda Naktinienè (vyr. redaktorè), Jonas Paulauskas, Ritutė Petrokienė, Vytautas Vitkauskas, Jolanta Zabarskaite, Vilnius: Lietuvių kalbos institutas, 2005, atnaujinta elektroninė versija, 2017. Prieiga internete: https://ekalba.lt/lietuviu-kalbos-zodynas.

\section{Literatūra}

Anglickienè, Laima. 2006. Kitataučiu įvaizdis lietuvių folklore. Vilnius: Versus aureus.

Baldāne, Ilze. 2014.

Latvian Ethnic Stereotypes: Studies and Results. Vida Savoniakaitė (sud.). Savas ir kitas šiuolaikiniais požiüriais. Vilnius: Lietuvos istorijos institutas, 139-157.

Cidzikaitè, Dalia. 2007. Kitas lietuviu prozoje. Vilnius: Lietuvių literatūros ir tautosakos institutas.

Čižik-Prokaševa, Veslava. Lenkè dabartinès lietuvių kalbos tekstyne. Lietuviu kalba 14, 2020. 1-12. Prieiga internete: https://www.zurnalai.vu.lt/lietuviukalba/article/view/22459/ 21721.

Daugirdaitè, Vilma. 2007. Kas šiandien pasakojama latvių ir apie latvius Žemaitijoje. Tautosakos darbai 34, 243-256.

Ereminas, Gintautas. 2021. Latviai. Visuotine lietuviu enciklopedija: elektroninis variantas. Vilnius: Mokslo ir enciklopediju leidybos centras. Prieiga internete: https://www.vle.lt/straipsnis/latviai/. 
Gudavičius, Aloyzas. 2007. Gretinamoji semantika. Šiauliai: Bibliotheca actorum Humanitaricorum universitatis Saulensis.

Gudavičius, Aloyzas. 2009. Etnolingvistika: Tauta kalboje. Šiauliai: Šiaulių universiteto leidykla.

Gudavičius, Aloyzas. 2011. Reikšmè - sąvoka - konceptas ir prasmè. Res Humanitariae X, 108-119.

Jakaitienė, Evalda. 1988. Leksinè semantika. Vilnius: Mokslas.

Jakaitiené, Evalda. 2010. Leksikologija. Vilnius: Vilniaus universiteto leidykla.

Jonutytè, Jurga. 2013.

Žeimelio atminties pasakojimai. Jurga Jonutyte, Lina Būgienė, Aleksandras Krasnovas. Lietuvos pasienio miesteliu atmintis ir tapatybè: Valkininkai, Vilkyškiai, Žeimelis, Vilnius: Vilniaus universitetas, 171-176.

Karaliūnas, Simas. 1997. Kalba ir visuomene (Psichologiniai ir komunikaciniai kalbos vartojimo bruožai). Vilnius: Lietuvių kalbos institutas.

Kvašytè, Regina. 2012. T Tarp Lietuvos ir Latvijos: lingvistinès paralelès. Šiauliai: Šiaulių universiteto leidykla.

Myers, David. 2008. Socialine psichologija. Vilnius: Poligrafija ir informatika.

Noreikaitè, Auksè. 2017. Lietuvių ir latvių tarpusavio santykiai Lietuvos ir Latvijos pasienyje. Gimtasai kraštas: praeities ir dabarties kultūros metraštis T. 1, Kaunas: Žiemgalos leidykla, 17-26.

Noreikaitè, Auksè. 2013. Lietuvių ir latvių tarpusavio santykiai Lietuvos ir Latvijos pasienyje. Magistro darbas. Kaunas: VDU.

Pajèdienè, Jūratè. 2021. Svetimo pasaulio prisijaukinimas šiaurès vakarų žemaičių kalbèjime. Pranešimas tarptautinèje mokslinèje konferencijoje „Kalbu ir kultūru squeika Europoje: paribių zonos ir kontaktinès erdvès" Vilniuje $2021 \mathrm{~m}$. rugsèjo $10 \mathrm{~d}$.

Papaurèlyte்-Klovienè, Silvija. 2010.

Kaimyninių tautų atstovai ir jų nacionalinio charakterio specifika lietuvių kalbos pasaulèvaizdyje. Lietuvių kalba 4, 1-9. Prieiga internete: http://www.lietuviukalba.lt/index.php/lietuviu kalba/ article/view/27.

Petrušauskaitè, Vita. 2013. Etninès ir socialinès grupès Lietuvoje: visuomenès nuostatos ir ju kaita 2013 metais. Etniškumo studijos 1-2, 180-191. Prieiga internete: http://www.ces.lt/wp-content/uploads/2014/10/2013_2Etniskumo-studijos.180-191.pdf.

Ryžakova, Svetlana I., Etničeskie obrazy $i$ stereotipy po rezultatam sravnitelnogo issledoZavijalova Marija V. 2008. vanija sredi molodeži Latvii i Litvy (1999-2003 gg.). Moskva: Institut ètnologii i antropologii RAN.

Rutkovska, Kristina,

Smetonienè, Irena, Vertybès lietuvio pasaulèvaizdyje. Vilnius: Akademinè leidykla.

Smetona, Marius. 2017.

Rutkovska, Kristina. 2017a. Namai. Kristina Rutkovska, Irena Smetonienė, Marius Smetona. Vertybès lietuvio pasaulevaizdyje. Vilnius: Akademinè leidykla, 88-116.

Rutkovska, Kristina. 2017b. ̌̌eima. Kristina Rutkovska, Irena Smetonienè, Marius Smetona. Vertybès lietuvio pasaulevaizdyje. Vilnius: Akademinè leidykla, 116-148. 
Sakalauskienė, Vilija. 2018. ̌̌mogaus konceptualizavimas vakarų aukštaičių kauniškių šnektų žodynuose. Kalbos istorijos ir dialektologijos problemos 5, 167-188.

Senvaitytè, Dalia. 2004. Etninių stereotipų kaita: tautybès studentų akimis. Tiltai 4, 123-129.

Smetona, Marius. 2019a. Sąvokų formavimosi ypatybès. Irena Smetonienè, Marius Smetona Kristina Rutkovska. Kalba. Tauta. Valstybe, Vilnius: Vilniaus universiteto leidykla, 17-46.

Smetona, Marius. 2019b. Anketų aprašas. Irena Smetonienè, Marius Smetona Kristina Rutkovska. Kalba. Tauta. Valstybé, Vilnius: Vilniaus universiteto leidykla, 76-115.

Smetonienè, Irena,

Kalba. Tauta. Valstybè. Vilnius: Vilniaus universiteto leidykla.

Smetona, Marius,

Rutkovska, Kristina. 2019.

Smetonienè, Irena. 2019.

Sintetinè analizè. Irena Smetonienè, Marius Smetona Kristina Rutkovska. Kalba. Tauta. Valstybé, Vilnius: Vilniaus universiteto leidykla, 172-178.

Smith, Anthony. 1994.

Nacionalizmas XX amžiuje. Vilnius: Pradai.

Tissari, Heli. 2008.

Happiness and Joy in Corpus Contexts: A Cognitive Semantic Analysis. Heli Tissari, Anne Birgitta Pessi, Mikko Salmela (eds.). Happiness: Cognition, Experience, Language [COLLeGIUM: Studies across Disciplines in the Humanities and Social Sciences, Volume 3], 144-174. Prieiga internete: https://helda. helsinki.fi/handle/10138/25771.

Vaičiulytė-Semènienè, Draugo konceptas publicistikoje. Kristina Rutkovska, Stanisława Loreta. 2020. Niebrzegowska-Bartmińska (red.). Vertybès lietuviu ir lenku pasaulèvaizdyje 1. Teorinès prielaidos ir interpretacijos, Vilnius / Liublinas: VU leidykla, 337-365.

Vykepĕl, Bohumil. 2005. Hjelmslevo glosematika ir baltų kalbų fonologija. Vilnius: Sapnų sala.

Žigonis, Vytautas. 2010. Etnonimų čigonas, romas, žydas, karaimas, lenkas, rusas reikšmès tyrimai tekstynu lingvistikos metodu. Magistro darbas. Kaunas: VDU.

Loreta Vaičiulyté-Semeniene

Lietuviu kalbos institutas

P. Vileišio 5, LT-10308 Vilnius, Lietuva

ORCID: 0000-0003-2196-8937

loreta.semeniene@lki.lt 
KOPSAVILKUMS

\title{
Koncepts latvietis Mūsdienu lietuviešu valodas korpusa pasaules skatijumā
}

\author{
Loreta VAIČIULYTÉ-SEMĖNIENĖ
}

Analizējot 250 Mūsdienu lietuviešu valodas korpusā (MLVK) iekḷautus teikumus no publicētiem avotiem, kas satur dažādas lietvārda latvietis (lie. latvis) formas, atklājas diezgan daudzveidīgs latvieša portrets. Protams, ilustratīvie piemēri, pirmkārt un galvenokārt, atspoguḷo runātāja, t. i., lietuvieša, domāšanu, tomēr kopumā tie rāda visai vienveidīgu koncepta latvietis fragmentu.

N̦emot vērā līdzības starp latvieti un lietuvieti, kas ir fiksētas iepriekšējos pētīijumos un vārdnīcu škirirklos ar vārdu latvietis, šajā rakstā lietvārds analizēts no semantiskā viedokḷa. Izrādās, ka apgalvojumi par latvieti skar biolog̣iskos, (psiho)sociālos, psiholoǵiskos, sadzīves, fiziskos, lokālos un reliǵiskos aspektus. MLVK esošie piemēri galvenokārt atklāi pirmos trīs no šiem aspektiem. Bioloğiski lietuvietis latvieti uztver kā vienas g̊imenes locekli, kā tuvinieku. Tas nozīmē, ka lietuvietis pietiekami labi pazīst latvieti. Tas ietekmē lietuvieša uztveri par latvieša pozitīvajām un negatīvajām iezīmēm, no kurām dažas ir minētas arī atsevišksu autoru iepriekšējos pētījumos.

\section{SUMMARY}

\section{The Concept of Latvian in the Worldview of The Corpus of the Contemporary Lithuanian Language}

\section{Loreta VAIČIULYTĖ-SEMĖNIENĖ}

An analysis of 250 sentences from published sources containing different forms of the noun Latvian (Lith. latvis) that are featured in the Corpus of the Contemporary Lithuanian Language (CCLL) reveals a rather diverse portrait of the Latvian. Of course, the illustrative examples mirror the mindset of the speaker, i.e. the Lithuanian, first and foremost, yet taken as a whole they allow one to draw a conclusion of a rather uniform fragment of the concept of the Latvian.

Considering the similarities between the Latvian and the Lithuanian that have been recorded in prior studies and dictionary entries with the word Latvian, this article approaches the noun from a semantic perspective. It turns out that statements regarding the Latvian concern biological, (psycho)social, psychological, domestic, physical, local, and religious aspects. The examples available in the CCLL mainly reveal the first three of these aspects. Biologically, the Lithuanian perceives the Latvian as a member of the same family; a close one. This means that the Lithuanian knows the Latvian well enough. This affects the Lithuanian's perception of the positive and negative traits of the Latvian, some of which have been mentioned in previous studies by individual authors. 